\title{
RESEARCH PAPER \\ Effect of organic and inorganic fertilization on weed flora and seed yield in black mustard [Brassica nigra (L.) Koch] crops
}

\author{
Ioanna Kakabouki, Stella Karydogianni, Ioannis Roussis, and Dimitrios \\ Bilalis
}

Agricultural University of Athens, School of Plant Sciences, Department of Crop Science, Laboratory of Agronomy. 75 Iera Odos Str., 11855 Athens, Greece.

\begin{abstract}
I. Kakabouki, S. Karydogianni, I. Roussis, and D. Bilalis. 2020. Effect of organic and inorganic fertilization on weed flora and seed yield in black mustard [Brassica nigra (L.) Koch] crops. Int. J. Agric. Nat. Resour. 79-89. Crop production practices affect weed communities in agricultural systems. Field experiments were conducted to determine the effects of organic and inorganic fertilization on weed flora and seed yield in black mustard [Brassica nigra (L.) Koch] crops. The experiments, conducted at two sites (Athens and Agrinio, Greece) during 2019, were laid out in a randomized complete block design with three replicates and three fertilization treatments (untreated, compost fertilizer and inorganic fertilizer). The results of the present study indicated that the total weed density and biomass in the black mustard crops were significantly influenced by fertilization. The highest leaf area index $\left(4.76-4.84 \mathrm{~m}^{2} \mathrm{~m}^{-2}\right)$ and canopy interception of incident photosynthetically active radiation (PAR) (93.56-94.98\%) were observed under inorganic fertilization at 90 days after sowing. At both experimental sites, the total weed density and biomass were significantly higher under inorganic fertilizer treatment at 45 DAS. The highest densities of the weed species Sinapis arvensis, Chenopodium album and Malva sylvestris were found in the plots treated with inorganic fertilizer. The seed yield was also affected by fertilization, with the highest values (1352-1456 $\left.\mathrm{kg} \mathrm{ha}^{-1}\right)$ observed in the plots treated with inorganic fertilizer. In conclusion, the different fertilization practices affected both the weed density and weed biomass; in particular, inorganic fertilization led to the development of he highest weed density. Furthermore, the highest seed yields were recorded under inorganic fertilization in both the experimental areas.
\end{abstract}

Keywords: Black mustard, compost, diversity indices, inorganic fertilizer, weed density, weed management.

\section{Introduction}

Black mustard [Brassica nigra (L.) Koch, Family: Brassicaceae] is an annual herbaceous plant whose exact native range is uncertain, but this plant is probably endemic to the southern Medi-

Received Sep 16, 2019. Accepted Jun 10, 2020.

Corresponding author: bilalisdimitrios@gmail.com terranean region (Thomas et al., 2004). Sinskaia (1928) identified two major geographic forms of $B$. nigra, a western form that was grown in Europe, Africa, Asia Minor and Afghanistan and an eastern form that was grown in India and as far west as the Syrian Arab Republic and Palestine. Black mustard was one of the first domesticated crops and was widely grown in central and southern 
Europe, North Africa and Asia due to the sharp pungency of its seeds and as a leaf vegetable. In addition to its use as a condiment, the medicinal value of black mustard was also recognized early, as mustard meal mixed with water was extensively used to prepare plaster and mustard baths to treat skin ailments, arthritis, and rheumatism (Thomas et al., 2004). Until the 1950s, black mustard was the world's major source of pungent mustard, but it was then displaced by the higher yielding, pungent brown mustard [B. juncea (L.) Czernjaew], which was better suited to large-scale and mechanized cultivation (Prakash \& Hinata, 1980).

Interest in the cultivation of black mustard has recently increased, and it has been introduced to areas outside of its native continents, such as Australia and America, as a source of edible oil and seeds (Sahay et al., 2015). This crop has been selected because of its ability to grow under diverse agroecological conditions, such as at relatively low temperatures and in disturbed soils, making it well adapted for cultivation for both domestic and industrial uses (Angelova \& Ivanova, 2009). In addition, black mustard production is also expected to undergo significant growth in the coming years mainly due to the increasing application of mustard seeds in the food and beverage, pharmaceutical, personal care, and cosmetic industries (Rahman et al., 2018).

A typical image of the black mustard plant includes a firm taproot, large lower leaves, smaller upper leaves and a stem that is lightly covered with soft hairs. Black mustard can be easily distinguished from the commercial Brassica crops in that it does not produce a rosette of basal leaves. Black mustard seeds are globular, 1-1.6 mm in diameter, dark brown to nearly black in color, minutely reticulate, and mucilaginous (Bagchi \& Srivastava, 2003).

Crop production practices affect weed communities in agricultural systems. Differentiation in the concentration and availability of plant nutrients could markedly affect crop-weed interference
(Murphy \& Lemerle, 2006). As a consequence of the utilization of the same sources, weeds could measurably reduce yield quality and quantity, which may cause financial damage. Proper management of crop nutrients assures sustainable weed management through the provision of suitable inputs for crop functioning (Di Tomaso, 1995).

Nitrogen constitutes the major nutrient that is added to increase crop yield. Many weed species consume large quantities of nitrogen, thus limiting crop-available nitrogen; however, certain weed species have a lower optimal nitrogen requirement than crops, giving those weeds a competitive advantage in some situations (Di Tomaso, 1995). Therefore, it is important to develop fertilization strategies for crop production that enhance the competitive ability of the crops, minimize weed competition, and reduce the risk of nonpoint source pollution from nitrogen (Sweeney et al., 2008).

Despite the numerous studies of new and promising crops worldwide, there is a clear lack of information on the combined effects of weed management and fertilization practices on black mustard crops. The current study aimed to investigate the effects of organic and inorganic fertilization on weed flora and seed yield in black mustard crops under Mediterranean conditions.

\section{Materials and Methods}

Two field experiments were conducted in 2019 at the organic experimental field of the Agricultural University of Athens (Latitude: $37^{\circ} 59^{\prime}$ $\mathrm{N}$, Longitude: $23^{\circ} 42^{\prime} \mathrm{E}$, Altitude: $29 \mathrm{~m}$ above sea level) in Athens, Greece, and at an organic field in the Agrinio region (Latitude: $38^{\circ} 35^{\prime} \mathrm{N}$, Longitude: $21^{\circ} 25^{\prime} \mathrm{E}$, Altitude: $80 \mathrm{~m}$ above sea level) located in western Greece. The soil type was clay loam in Athens and silt loam in Agrinio (Table 1). The mean values of the meteorological data concerning air temperature and precipitation at the experimental sites are presented in 
Figure 1. The sites were managed according to organic agricultural guidelines (EC 834/2007).

Table 1. Soil properties in the experimental sites (Athens and Agrinio).

\begin{tabular}{lcc}
\hline Soil Properties & Athens & Agrinio \\
\hline Soil Type & Clay loam & Silt loam \\
Clay & $29.8 \%$ & $24.9 \%$ \\
Silt & $34.3 \%$ & $61.2 \%$ \\
Sand & $35.9 \%$ & $13.9 \%$ \\
pH $\left(1: 1 \mathrm{H}_{2} \mathrm{O}\right)$ & 7.21 & 7.44 \\
Organic matter & $1.39 \%$ & $1.46 \%$ \\
CaCO & & $14 \%$ \\
Total Nitrogen & $0.114 \%$ & $0.153 \%$ \\
Phosphorus $-\mathrm{P}$ Olsen & $49 \mathrm{mg} \mathrm{kg}^{-1}$ soil & $175 \mathrm{mg} \mathrm{kg}^{-1}$ soil \\
Potassium & $341 \mathrm{mg} \mathrm{kg}^{-1}$ soil & $632 \mathrm{mg} \mathrm{kg}^{-1}$ soil \\
\hline
\end{tabular}

Each experiment was set up on a $352-\mathrm{m}^{2}$ area according to a randomized complete block design (RCBD) with three fertilization treatments: control (untreated), farmyard manure $(2000 \mathrm{~kg}$ $\mathrm{ha}^{-1}$, solid, $1.52 \% \mathrm{~N}$ ) and inorganic fertilizer (300 $\mathrm{kg} \mathrm{ha}^{-1}$ Nutrimore Winner 40-0-0+14.5 $\mathrm{SO}_{3}$, Gavriel Ltd.), with three replicates for each treatment. The plot size was $32 \mathrm{~m}^{2}(8 \mathrm{~m} \times 4 \mathrm{~m})$.
There were spaces of $1 \mathrm{~m}$ between replicates and $1 \mathrm{~m}$ between plots. The cultivated species was black mustard [B. nigra (L.) Koch]. The soil was prepared by plowing to a depth of approximately $25 \mathrm{~cm}$. Fertilizers were applied by hand on the soil surface and then harrowed in. Seed sowing was performed on the $18^{\text {th }}$ and $20^{\text {th }}$ of January 2019 in Athens and Agrinio, respectively. The sowing distances were $30 \mathrm{~cm}$ between rows and $15 \mathrm{~cm}$ within each row. The mean monthly temperature and total precipitation during the growing period (January-June 2019) were $15.9^{\circ} \mathrm{C}$ and $330.8 \mathrm{~mm}$, respectively, in Athens and $15.1^{\circ} \mathrm{C}$ and $422.8 \mathrm{~mm}$, respectively, in Agrinio.

The sampling dates for all the variables at both the experimental sites were $45,60,75,90$, and 105 days after sowing (DAS). The leaf area index (LAI) and the canopy interception of incident photosynthetically active radiation (PAR) were measured by taking 5 readings in rapid succession in each plot using a SunScan SS1 plant canopy analyzer (Delta-T Devices, Cambridge, UK). The SunScan meter consists of a 1-m long SunScan probe with 64 photodiodes for the below canopy radiation in the wavelength range $400-700 \mathrm{~nm}$ and

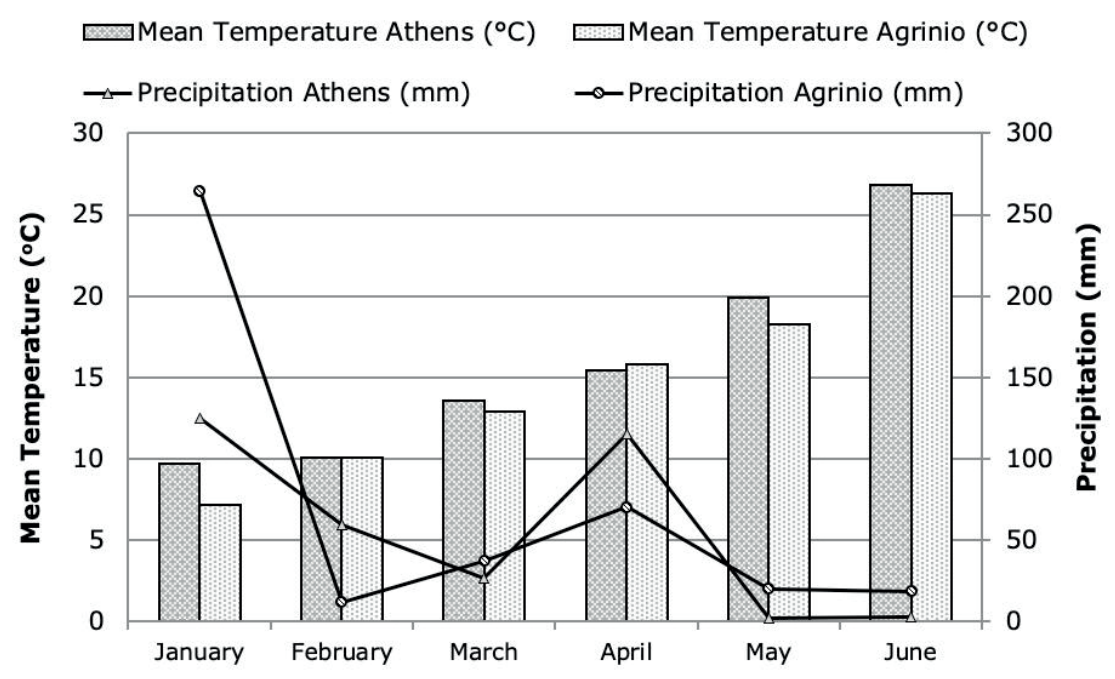

Figure 1. Mean monthly temperature and precipitation for the experimental sites (Athens and Agrinio) during the cultivation period (January-June 2019). 
a beam fraction sensor for the above canopy radiation. The above and below canopy measurements were performed at the same time. The LAI was calculated by the data collection terminal connecting the SunScan probe and the beam fraction sensor by applying Wood's SunScan equations, which are based on the Beer-Lambert extinction law, and taking into account other parameters, such as the absorption and transmission of diffuse light and zenith angles (Webb et al., 2013). The fraction of the incident PAR intercepted by the canopy $\left(F_{\text {int }}\right.$ PAR) was calculated with the following equation (Bilalis et al., 2010):

$$
\% F_{\text {int }} \text { PAR }=\left(1-\frac{P A R \text { below canopy }}{\text { PAR above canopy }}\right) \times 100
$$

The weed density was assessed using a wooden square quadrat $(0.5 \times 0.5 \mathrm{~m})$ placed at random in two locations in each plot. All the weeds were collected from the measured area and weighed to determine the weed dry matter. The weed dry matter was measured after drying for $72 \mathrm{~h}$ at $70^{\circ} \mathrm{C}$.

The species diversity of the weed groups was characterized using the Simpson $(D)$ and ShannonWiener indices $(H)$ using the following formulas (Booth et al., 2003):

$D=1 / \sum_{\mathrm{i}=1}^{\mathrm{s}} P i^{2}$ and $H=-\sum_{\mathrm{i}=1}^{\mathrm{s}}(P i)(\ln P i)$

where $P \mathrm{i}$ is the proportion of individuals belonging to the $i^{\text {th }}$ species, and $s$ is the total number of species in a given group. The values of the ShannonWiener diversity index range between 1.5 and 3.5 (MacDonald, 2003). To calculate these indices, the Species Diversity and Richness IV software (Pisces Conservation Ltd., New Milton, UK) was used. The above mentioned indices increase either with the addition of unique species or with greater species evenness (Booth et al., 2003).

Finally, to estimate the seed yield, 10 black mustard plants were randomly selected in each plot at 140 DAS and harvested in bags to prevent seed shatter.
The experimental data were subjected to statistical analysis according to randomized complete block design (RCBD). The statistical analysis was performed using SigmaPlot 12 statistical software (Systat Software Inc., San Jose, CA, USA). Differences between means were distinguished using the least significant difference (LSD) test. Correlation analyses were used to describe the relationships between the LAI, $F_{\text {int }}$ PAR, weed species diversity indices and seed yield using Pearson's correlation. All the comparisons were made at the $5 \%$ level of significance.

\section{Results and Discussion}

The effect of fertilization on the leaf area index (LAI) is shown in Table 2. During the growing season, there were significant differences among fertilization regimes. The maximum values of the LAI were recorded at 90 DAS. The LAI was significantly higher in the plots treated with inorganic fertilization (4.76 and $4.84 \mathrm{~m}^{2} \mathrm{~m}^{-2}$ in Athens and Agrinio, respectively), while the lowest values (3.87 and $3.93 \mathrm{~m}^{2} \mathrm{~m}^{-2}$ in Athens and Agrinio, respectively) were observed in the control plots. In addition, there was a significant difference in the LAI values between the locations, with the highest values observed in the Agrinio area. This result is probably related to the higher precipitation patterns observed at this experimental site. Depending on the local precipitation and available soil water reserves, the LAI of a crop with an adequate water supply increases, specially early in the growing season, as a result of earlier and more rapid leaf production in the vegetative growth phase (Grashoff et al., 1995).

The values of $F_{\text {int }}$ PAR under different fertilization regimes are presented in Table 2. From 45 until 75 DAS, there was a significant and rapid increase in the fraction of PAR that was intercepted. The maximum values were observed in the flowering stage (75 and 90 DAS), especially at 90 DAS. Across all the treatments and at both experimental sites, the $F_{\text {int }}$ PAR values during the 
Table 2. Leaf area index (LAI) and Fint PAR (fraction of PAR (\%) intercepted by crop canopy) as affected by fertilization (control, compost fertilizer, or inorganic fertilizer) during the growing season in Athens and Agrinio.

\begin{tabular}{|c|c|c|c|c|c|}
\hline \multirow{2}{*}{ Fertilization } & \multicolumn{5}{|c|}{ Leaf Area Index $\left(\mathrm{m}^{2} \mathrm{~m}^{-2}\right)$} \\
\hline & 45 DAS & 60 DAS & 75 DAS & 90 DAS & 105 DAS \\
\hline \multicolumn{6}{|l|}{ Athens } \\
\hline Control & 1.93 & 3.14 & 3.73 & 3.87 & 3.79 \\
\hline Compost & 2.17 & 3.52 & 4.20 & 4.35 & 4.27 \\
\hline $\begin{array}{l}\text { Inorganic fertil- } \\
\text { izer }\end{array}$ & 2.31 & 3.80 & 4.56 & 4.76 & 4.56 \\
\hline$F_{\text {fertilization }}$ & $\begin{array}{c}9.67^{*} \\
(\mathrm{LSD}=0.213)\end{array}$ & $\begin{array}{c}10.99 * * \\
(\mathrm{LSD}=0.342)\end{array}$ & $\begin{array}{c}23.74 * * \\
(\mathrm{LSD}=0.295)\end{array}$ & $\begin{array}{c}30.97 * * * \\
(\mathrm{LSD}=0.278)\end{array}$ & $\begin{array}{c}10.70^{*} \\
(\mathrm{LSD}=0.410)\end{array}$ \\
\hline \multicolumn{6}{|l|}{ Agrinio } \\
\hline Control & 2.04 & 3.25 & 3.82 & 3.93 & 3.86 \\
\hline Compost & 2.28 & 3.58 & 4.29 & 4.43 & 4.25 \\
\hline $\begin{array}{l}\text { Inorganic fertil- } \\
\text { izer }\end{array}$ & 2.44 & 3.91 & 4.68 & 4.84 & 4.63 \\
\hline \multirow[t]{3}{*}{$F_{\text {fertilization }}$} & $\begin{array}{c}11.24 * * \\
(\mathrm{LSD}=0.208)\end{array}$ & $\begin{array}{c}8.32 * \\
(\mathrm{LSD}=0.399)\end{array}$ & $\begin{array}{c}28.90 * * * \\
(\mathrm{LSD}=0.273)\end{array}$ & $\begin{array}{c}26.02 * * \\
(\mathrm{LSD}=0.311)\end{array}$ & $\begin{array}{c}9.48^{*} \\
(\mathrm{LSD}=0.382) \\
\end{array}$ \\
\hline & \multicolumn{5}{|c|}{ Fint PAR (\%) } \\
\hline & 45 DAS & 60 DAS & 75 DAS & 90 DAS & 105 DAS \\
\hline \multicolumn{6}{|l|}{ Athens } \\
\hline Control & 38.64 & 52.91 & 67.09 & 75.89 & 72.84 \\
\hline Compost & 43.62 & 59.93 & 75.58 & 85.77 & 81.12 \\
\hline $\begin{array}{l}\text { Inorganic } \\
\text { fertilizer }\end{array}$ & 46.35 & 63.76 & 82.35 & 93.56 & 87.30 \\
\hline $\mathrm{F}_{\text {fertilization }}$ & $\begin{array}{c}9.93 * \\
(\operatorname{LSD}=4.397)\end{array}$ & $\begin{array}{c}9.68^{*} \\
(\mathrm{LSD}=6.116)\end{array}$ & $\begin{array}{c}25.30^{* *} \\
(\operatorname{LSD}=5.261)\end{array}$ & $\begin{array}{c}26.22 * * \\
(\operatorname{LSD}=5.986)\end{array}$ & $\begin{array}{c}6.02 * \\
(\mathrm{LSD}=10.19)\end{array}$ \\
\hline \multicolumn{6}{|l|}{ Agrinio } \\
\hline Control & 41.40 & 56.27 & 70.67 & 76.69 & 73.91 \\
\hline Compost & 46.91 & 64.61 & 78.87 & 87.96 & 84.55 \\
\hline $\begin{array}{l}\text { Inorganic } \\
\text { fertilizer }\end{array}$ & 49.86 & 69.10 & 87.13 & 94.98 & 90.27 \\
\hline $\mathrm{F}_{\text {fertilization }}$ & $\begin{array}{c}10.39^{*} \\
(\mathrm{LSD}=4.629)\end{array}$ & $\begin{array}{c}8.05^{*} \\
(\mathrm{LSD}=7.419)\end{array}$ & $\begin{array}{c}33.47 * * * \\
(\mathrm{LSD}=4.922)\end{array}$ & $\begin{array}{c}19.35^{* *} \\
(\mathrm{LSD}=7.261)\end{array}$ & $\begin{array}{c}10.41^{*} \\
(\operatorname{LSD}=8.911)\end{array}$ \\
\hline
\end{tabular}

F-test ratios are from ANOVA. The symbols $* * *$ and $* * *$ indicate significance at $\mathrm{p}=0.05,0.01$ and 0.001 , respectively, and ns indicates not significant $(\mathrm{p}>0.05)$. The least significant difference (LSD) test $(\mathrm{p}=0.05)$ values for fertilization are also presented.

reproductive phase (105 DAS) were higher than those of the vegetative phase (45 and 60 DAS). The mean values of $F_{\text {int }}$ PAR provide good evidence of the effects of the fertilization regimes. In the inorganic fertilizer treatment group the values of $F_{\text {int }}$ PAR were substantially higher (93.56 and 94.98\% in Athens and Agrinio, respectively) than in the compost treatment group (85.77 and $87.96 \%$ in Athens and Agrinio, respectively). The lowest values (75.89 and 76.69\% in Athens and Agrinio, respectively) were found in the untreated (control) plots. In addition, there was a very strong positive correlation between the LAI and $F_{\text {int }}$ PAR at both the experimental sites $(r=0.9073, p<0.001$ and $r=0.9110, p<0.001$, in Athens and Agrinio area, respectively, at $90 \mathrm{DAS})$. This result indicates that the increased LAI resulted in an increase in the fraction of PAR that was intercepted.

Nitrogen is an important element in augmenting crop production. A sufficient application of nitrogen results in the rapid development of 
the leaf canopy, enabling plants to intercept more solar radiation and thus resulting in higher photosynthesis (Mokhtassi-Bidgoli et al., 2013). Crop growth depends on the ability of the canopy to intercept the incoming radiation, which is a function of the leaf area index and canopy architecture, and on its conversion into plant biomass (Gifford et al., 1984) According to the model elaborated by Monteith (1981), biomass production can be presented as a linear function of the photosynthetically active radiation (PAR; wavelength 400-700 nm) that was intercepted by the canopy. Increased interception of solar radiation constitutes a main factor for increased dry matter production in crops. Previous studies have shown that higher biomass production results from more intercepted solar radiation (Bilalis et al., 2010; Mokhtassi-Bidgoli et al., 2013).

The ten major weed species in the Athens and Agrinio experimental trials are presented in Figure 2. The weed community was dominated by Sinapis arvensis (Brassicaceae), Matricaria chamomilla (Asteraceae), Chenopodium album (Chenopodiaceae), Malva sylvestris (Malvaceae), Galium aparine (Rubiaceae) and Papaver rhoeas (Papaveraceae) in Athens, and the most dominant weed species in the Agrinio area were S. arvensis, C. album, M. chamomilla, M. sylvestris and Fumaria officinalis (Papaveraceae). The total weed density was significantly affected by the different fertilization regimes (Table 3). The maximum values were observed at $45 \mathrm{DAS}$, and then, the values gradually declined until the end of measurements (105 DAS). At both the sites, the highest weed densities (38.7 and 34.2 plants $\mathrm{m}^{-2}$ in Athens and Agrinio, respectively) were recorded in the plots treated with inorganic fertilizer. Similar trends were also found with weed dry matter. The highest weed dry matter was also observed in the inorganic treatment group at 45 DAS, with the values being 30.02 and $26.63 \mathrm{~g} \mathrm{~m}^{-2}$ for Athens and Agrinio, respectively.

The canopy structure of both crop and weeds may influence the level of competition. Stem height, leaf area, leaf angle, and leaf arrangement within the canopy can define the ability of a crop to intercept photosynthetically active radiation (PAR). Canopy structure can affect the amount of light intercepted by the crop, which in turn can define crop growth (Bilalis et al., 2010). The increasing ability of black mustard crops to compete with weeds during the growth cycle may be associated with the increase in the high overall leaf area and in the planophile leaves (high $\mathrm{k}_{\text {leaf }}$ ) of these plants.

High crop productivity has been demonstrated to occur simultaneously with greater frequency of weed species in arable crops (Bischoff \& Mahn, 2000). In our study, the increase in weed density with increasing available nitrogen (the inorganic fertilizer contained soluble inorganic nitrogen with rapid availability for plant species) may be due to the positive effect of nitrogen on the germination and effective stand growth of weeds. In addition, most of the weed species are reported to be efficient nitrogen users. The results obtained are
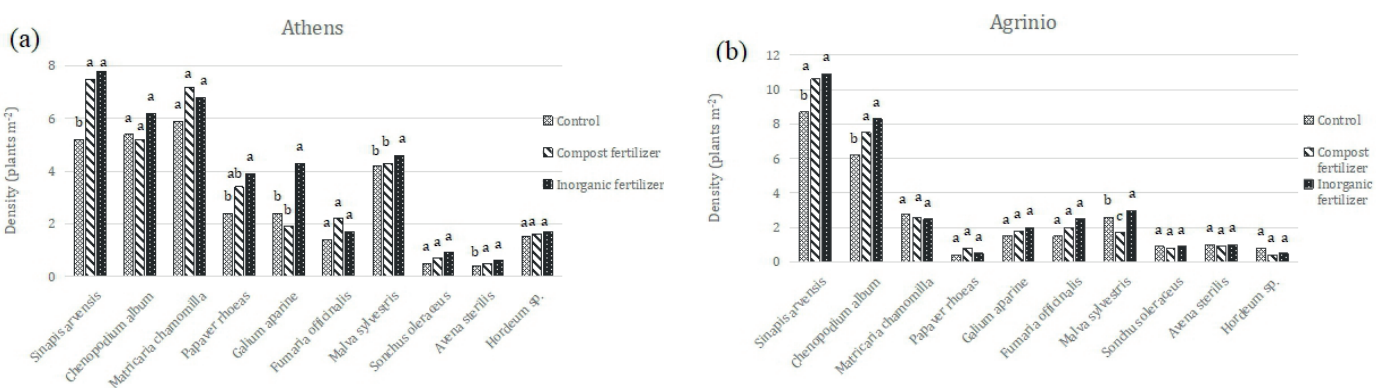

Figure 2. Density of the ten major weeds (plants $\mathrm{m}^{-2}$ ) as affected by fertilization (control, compost ertilizer, or inorganic fertilizer) in (a) Athens and (b) Agrinio. The different lower case letters denote statistically significant differences $(p<0.05)$ according to the LSD test. 
Table 3. Weed density (plants $\left.\mathrm{m}^{-2}\right)$ and weed dry matter $\left(\mathrm{g} \mathrm{m}^{-2}\right)$ as affected by fertilization (control, compost fertilizer, or inorganic fertilizer) during the growing season in Athens and Agrinio.

\begin{tabular}{|c|c|c|c|c|c|}
\hline \multirow{2}{*}{ Fertilization } & \multicolumn{5}{|c|}{ Weed Density (plants $\mathrm{m}^{-2}$ ) } \\
\hline & 45 DAS & 60 DAS & 75 DAS & 90 DAS & $105 \mathrm{DAS}$ \\
\hline \multicolumn{6}{|l|}{ Athens } \\
\hline Control & 30.8 & 26.7 & 21.2 & 19.0 & 14.8 \\
\hline Compost & 35.1 & 29.9 & 24.0 & 22.3 & 16.1 \\
\hline Inorganic fertilizer & 38.7 & 32.6 & 26.3 & 23.1 & 17.4 \\
\hline $\mathrm{F}_{\text {fertilization }}$ & $\begin{array}{c}18.83 * * \\
(\mathrm{LSD}=3.19)\end{array}$ & $\begin{array}{c}16.22 * * \\
(\mathrm{LSD}=2.58)\end{array}$ & $\begin{array}{c}21.13^{* *} \\
(\mathrm{LSD}=1.86)\end{array}$ & $\begin{array}{c}13.34 * * \\
(\mathrm{LSD}=2.07)\end{array}$ & $\begin{array}{c}6.07 * \\
(\operatorname{LSD}=1.92)\end{array}$ \\
\hline \multicolumn{6}{|l|}{ Agrinio } \\
\hline Control & 27.3 & 24.8 & 19.4 & 17.3 & 14.7 \\
\hline Compost & 30.9 & 27.4 & 22.1 & 19.2 & 16.8 \\
\hline Inorganic fertilizer & 34.2 & 29.7 & 23.2 & 21.2 & 16.6 \\
\hline \multirow[t]{3}{*}{$\mathrm{F}_{\text {fertilization }}$} & $\begin{array}{c}30.10 * * * \\
(\mathrm{LSD}=2.11)\end{array}$ & $\begin{array}{c}18.78^{* *} \\
(\mathrm{LSD}=1.99)\end{array}$ & $\begin{array}{c}14.02 * * \\
(\mathrm{LSD}=1.89)\end{array}$ & $\begin{array}{c}8.38^{*} \\
(\mathrm{LSD}=2.42)\end{array}$ & $5.16^{\mathrm{ns}}$ \\
\hline & \multicolumn{5}{|c|}{ Weed Dry Matter $\left(\mathrm{g} \mathrm{m}^{-2}\right)$} \\
\hline & 45 DAS & $60 \mathrm{DAS}$ & 75 DAS & 90 DAS & 105 DAS \\
\hline \multicolumn{6}{|l|}{ Athens } \\
\hline Control & 24.06 & 21.29 & 18.86 & 16.84 & 14.47 \\
\hline Compost & 27.23 & 24.37 & 21.29 & 19.86 & 15.08 \\
\hline Inorganic fertilizer & 30.02 & 26.96 & 23.39 & 20.48 & 16.02 \\
\hline $\mathrm{F}_{\text {fertilization }}$ & $\begin{array}{c}12.79 * * \\
(\mathrm{LSD}=2.883)\end{array}$ & $\begin{array}{c}19.55^{* *} \\
(\mathrm{LSD}=2.224)\end{array}$ & $\begin{array}{c}22.38 * * \\
(\mathrm{LSD}=1.658)\end{array}$ & $\begin{array}{c}17.67^{* *} \\
(\operatorname{LSD}=1.602)\end{array}$ & $2.54^{\mathrm{ns}}$ \\
\hline \multicolumn{6}{|l|}{ Agrinio } \\
\hline Control & 22.38 & 17.75 & 16.77 & 14.43 & 12.57 \\
\hline Compost & 24.50 & 20.20 & 19.48 & 16.08 & 14.31 \\
\hline Inorganic fertilizer & 26.63 & 22.18 & 20.69 & 17.51 & 14.35 \\
\hline $\mathrm{F}_{\text {fertilization }}$ & $\begin{array}{c}31.11 * * * \\
(\mathrm{LSD}=1.319)\end{array}$ & $\begin{array}{c}31.73 * * * \\
(\mathrm{LSD}=1.364)\end{array}$ & $\begin{array}{c}13.65^{* *} \\
(\mathrm{LSD}=1.879)\end{array}$ & $\begin{array}{c}8.26^{*} \\
(\mathrm{LSD}=1.846)\end{array}$ & $\begin{array}{c}6.20^{*} \\
(\mathrm{LSD}=1.419)\end{array}$ \\
\hline
\end{tabular}

F-test ratios are from ANOVA. The symbols * ** and *** indicate significance at $\mathrm{p}=0.05,0.01$ and 0.001 , respectively, and ns indicates not significant $(\mathrm{p}>0.05)$. The least significant difference (LSD) test $(\mathrm{p}=0.05)$ values for fertilization are also presented.

in line with those of previous studies that have similarly observed that weed density and biomass significantly increased with an increase in the available nitrogen concentration (Blackshaw et al., 2003; Deniya et al., 2014).

The response of weed density to organic and inorganic fertilization was species specific. In particular, the greatest weed density was recorded for the species $S$. arvensis, C. album, M. chamomilla, and $M$. sylvestris. The densities of $S$. arvensis, $C$. album and $M$. sylvestris were significantly higher in the inorganic fertilization plots, while there were no significant differences in the density of M. chamomilla between fertilization treatments.
As reported by Bischoff \& Mahn (2000), weeds such as $S$. arvensis, $C$. album and M. sylvestris increased in density as the nitrogen application rate increased. Blackshaw et al. (1987) reported that a density of 20 plants $\mathrm{m}^{-2}$ of either $S$. arvensis or $C$. album caused a significant reduction in the seed yield of rapeseed (Brassica napus L.); however, $S$. arvensis caused greater reductions in the dry weight and seed yield of rapeseed than C. album. This observation could be explained by the similar growth habits and life cycles of $S$. arvensis and rapeseed, which would, therefore, compete more for specific resources and at similar times during the growing season. Moreover, Salisbury et al. (2018) indicated that weeds from the Brassicaceae family 
pose a threat through the potential deterioration of the product quality of rapeseed.

The diversity indices proposed by Shannon-Weiner and Simpson were useful in evaluating the effects of different fertilization patterns on the weed species population. In the present study, there were significant differences in the Shannon-Weiner $\left(F_{\text {fertilization }}=6.088, p=0.036\right.$ and $F_{\text {fertilization }}=20.078$, $p=0.002$, for Athens and Agrinio, respectively) and $\operatorname{Simpson}\left(F_{\text {fertilization }}=5.027, p=0.041\right.$ and $F_{\text {fer- }}$ tilization $=14.512, p=0.005$, for Athens and Agrinio, respectively) indices among the fertilization treatments. The lowest values of the ShannonWeiner (2.079 and 1.918 in Athens and Agrinio area, respectively) and Simpson (0.854 and 0.798 in Athens and Agrinio, respectively) indices were recorded under inorganic fertilization (Figure 3).

Fertilization could influence not only the species richness and diversity but also the size of the weed population and, therefore, the level of community evenness. An increase in the amount of available nitrogen in the soil could promote the existence of some dominant weed species and could result in decreases in species richness and diversity and an increase in species simplification (Tang et al., 2014). The observed differences in the densities and species richness of the weed communities between the locations can be ascribed to the different weed seed banks among the locations, the effects of fertilization on these seed banks, and environmental factors such as rainfall (Sweeney et al., 2008; Tang et al., 2014). Sweeney et al. (2008) reported that, in addition to nutrients and especially nitrogen, plant germination and growth are also affected by water availability.

Seed yield was negatively correlated with the Shannon-Weiner $(r=-0.5142, p=0.029$ and $r=-$ $0.5032, p=0.037$, for Athens and Agrinio, respectively) and Simpson ( $r=-0.4534, p=0.033$ and $r=-0.4315, p=0.042$, for Athens and Agrinio, respectively) indices. These results implied that a diverse weed community could not occur simultaneously with high black mustard seed production in these agroecosystems. The results of the present study indicated that the effect of organic and inorganic fertilization on seed yield was significant $\left(F_{\text {fertilization }}=14.779, p=0.004\right.$ and $F_{\text {fertilization }}=53.331, p<0.001$, respectively). The application of inorganic fertilizer resulted in consistently higher seed yield (Figure 4). In all cases, the seed yields of the plots treated with inorganic fertilizer were 6-9\% and $16-20 \%$ greater than the corresponding values of the plots treated with organic fertilizer and control, respectively.

The results of the present study confirmed that total weed density and biomass in black mustard crops were significantly influenced by different fertilization regimes. The application of inorganic fertilizer resulted in a higher leaf area index (LAI), which in turn resulted in an increase in the light interception by the canopy. The highest $F_{\text {int }}$ PAR values were also found under inorganic fertilization. At both
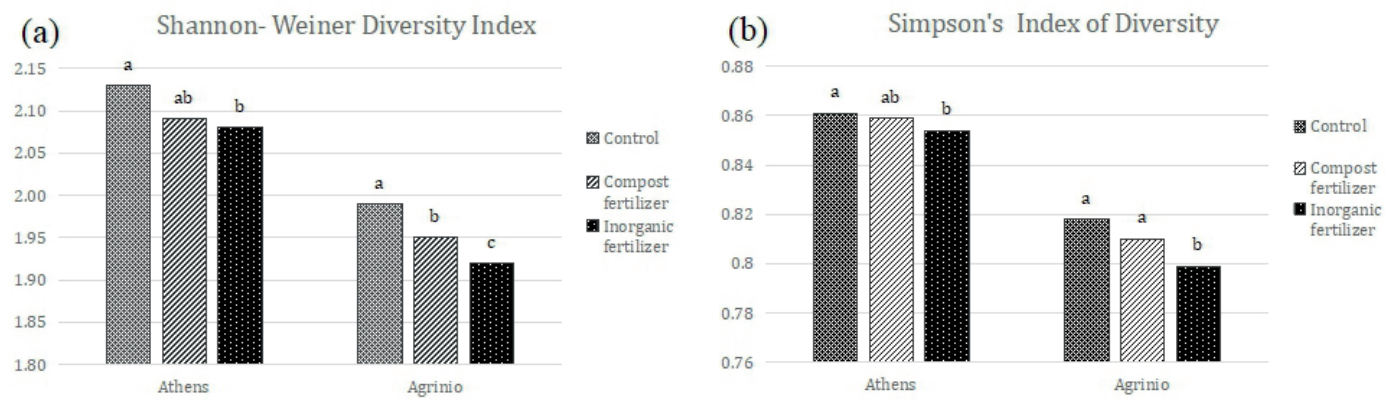

Figure 3. Effect of fertilization (control, compost fertilizer, or inorganic fertilizer) on the (a) Shannon-Weiner and (b) Simpson indices in Athens and Agrinio. The different lower case letters denote statistically significant differences $(\mathrm{p}<0.05)$ according to the LSD test. 


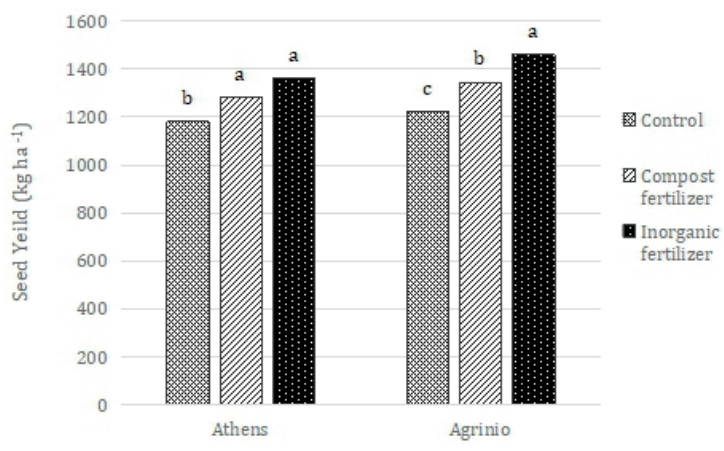

Figure 4. Seed yield as affected by fertilization (control, compost fertilizer, or inorganic fertilizer) in Athens and Agrinio. The different lower case letters denote statistically significant differences $(\mathrm{p}<0.05)$ according to the LSD test.

experimental sites, the total weed density and biomass were significantly higher in the inorganic fertilizer treatment group at 45 DAS. The highest densities of the weed species $S$. arvensis, C. album and $M$. sylvestris were found in the inorganic fertilization plots. There were no significant differences in the density of M. chamomilla between fertilization treatments. There is a clear need for further studies focusing on additional agronomic practices, such as soil tillage, seed rate and crop density as well as other strategies that may enhance crop competitiveness against weeds. In conclusion, the different fertilization practices affected both weed density and weed biomass; in particular, inorganic fertilization led to the development of the highest weed density. Furthermore, the highest seed yields were recorded under inorganic fertilization in both the experimental areas.

\section{Resumen}

I. Kakabouki, S. Karydogianni, I. Roussis, y D. Bilalis. 2020. Efecto de la fertilización orgánica e inorgánica sobre la flora de malezas y el rendimiento de semillas en cultivos de mostaza negra [Brassica nigra (L.) Koch]. Int. J. Agric. Nat. Resour. 79-89. Las prácticas de producción de cultivos influyen en las comunidades de malezas en los sistemas agrícolas. Se realizaron experimentos de campo para determinar los efectos de la fertilización orgánica e inorgánica en la flora de malezas y el rendimiento de semillas en cultivos de mostaza negra [Brassica nigra (L.) Koch]. Los experimentos realizados en dos sitios se presentaron en un diseño de bloques completos al azar con tres repeticiones y tres tratamientos de fertilización (sin tratar, compost y fertilizante inorgánico). El índice de área foliar más alto $\left(4.76-4.84 \mathrm{~m}^{2} \mathrm{~m}^{-2}\right)$ y la fracción del PAR incidente interceptado por el dosel (93.56-94.98\%) se encontraron bajo fertilización inorgánica a los 90 días después de la siembra. En ambos sitios experimentales, la densidad total de malezas y la biomasa fueron significativamente mayores en el tratamiento de fertilización inorgánica a los 45 días después de la siembra. La mayor densidad de especies de malezas Sinapis arvensis, Chenopodium album y Malva sylvestris se encontraron en las parcelas de fertilización inorgánica. El rendimiento de la semilla también se vio afectado por la fertilización con los valores más altos (1352-1456 kg ha'-1) observados en parcelas con fertilización inorgánica. .En conclusión, la diferente fertilización afectó tanto la densidad de malezas como la biomasa de malezas, y principalmente bajo fertilización inorgánica, donde se desarrolló la mayor densidad de malezas. Además, los mayores rendimientos de semillas se registraron en la fertilización inorgánica en ambas áreas, donde se llevaron a cabo los experimentos.

Palabras clave: Compost, densidad de malezas, fertilizantes inorgánicos, índices de diversidad, manejo de malezas, mostaza negra. 


\section{References}

Angelova, V., \& Ivanova, K. (2009). Bioaccumulation and distribution of heavy metals in black mustard (Brassica nigra Koch). Environmental Monitoring Assessment. 153:449-459.

Bagchi, G.D., \& Srivastava, N.G. (2003). Spices and flavoring crops: fruits and seeds. In: Caballero, B., L. Trugo, \& P.M. Finglas (Eds), Encyclopedia of Food Sciences and Nutrition. Academic Press, San Diego, CA, USA, pp. 5465-5477. 10.1016/B0-12-227055-X/01123-8

Bilalis, D., Papastylianou, P., Konstantas, A., Patsiali, S., Karkanis, A., \& Efthimiadou, A. (2010). Weed-suppressive effects of maize-legume intercropping in organic farming. International Journal of Pest Management. 56(2):173-181. 10.1080 / 09670870903304471

Bischoff, A., \& Mahn, E. G. (2000). The effects of nitrogen and diaspore availability on the regeneration of weed communities following extensification. Agriculture, Ecosystems and Environment. 77:237-246. 10.1016/S0167-8809(99)00104-8

Blackshaw, R.E., Anderson, W.G., \& Dekker, J. (1987). Interference of Sinapis arvensis L. and Chenopodium album L. in spring rapeseed (Brassica napus L.). Weed Research. 27:207-213.

Blackshaw, R.E., Brandt, N.R., Janzen, H.H, Grant, A.C., \& Derksen, A.D. (2003). Differential response of weed species to added nitrogen. Weed Science. 51:532-539. 10.1614 / 0043-1745

Booth, B.D., Murphy, D.S., \& Swanton, J.C. (2003). Weed ecology in natural and agricultural systems. CABI Publishing, Wallingford, UK. ISBN 0851995284

Deniya, E., Dadari, A.S., Ndahi, B.W., Kuchinda, C.N., \& Babaji, A.B. (2014). Effect of seed rate and nitrogen fertilizer on weed species composition, density and diversity in two sesame varieties. Archives of Agronomy and Soil Science. 61(4):553-567. 10.1080/03650340.2014.943666

Di Tomaso, J.M. (1995). Approaches for improving crop competitiveness through the manipulation of fertilization strategies. Weed Science. 43(3):491-497.
Gifford, R.M., Thorne, H.J., Hitz, D.W., \& Giaquinta, T.R. (1984). Crop productivity and photoassimilate partitioning. Science. 225: 801-808. 10.1126/science. 225.4664 .801

Grashoff, C., Dijkstra, P., Nonhebel, S., Schapendonk, A.H.C.M., \& van de Geijn, C.S. (1995). Effects of climate change on productivity of cereals and legumes; model evaluation of observed year-to-year variability of the $\mathrm{CO}_{2}$ response. Global Change Biology. 1(6):417-428.

MacDonald, G. (2003). Biogeography: Introduction to Space, Time, and Life. Blackwell Publishing, Hoboken, NJ, USA. ISBN-13: 978-0471241935

Mokhtassi-Bidgoli, A., Agha Alikhani, M., NassiriMahallati, M., Zand, E., Gonzalez-Andujar, J.L., \& Azari, A. (2013). Agronomic performance, seed quality and nitrogen uptake of Descurainia sophia in response to different nitrogen rates and water regimes. Industrial Crops Production. 44:583-592. doi.org/10.1016/j.indcrop.2012.09.018

Monteith, J.L. (1981). Climatic variations and growth of crops. Journal of Royal Meteorological Society. 107:749-774. doi.org/10.1002/ qj.49710745402

Murphy C.E., \& Lemerle, D. (2006). Continuous cropping systems and weed selection. Euphytica. 148:61-73. 10.1007/s10681-006-5941-9

Prakash, S., \& Hinata, K. (1980). Taxonomy, cytogenetics and origin of crop Brassicas, a review. Opera Botanica. 5:3-57.

Rahman, M., Khatun, A., Liu, L., \& Barkla, B.J. (2018). Brassicaceae mustards: Traditional and agronomic uses in Australia and New Zealand. Molecules. 23:231. 10.3390/molecules23010231

Salisbury, P.A., Potter, D.T., Gurum, M.A, Mailer, M R.J., \& Williams, W.M. (2018). Potential impact of weedy Brassicaceae on oil and meal quality of oilseed rape (canola) in Australia. Weed Research. 58(3): 200-209. 10.1111/wre.12296

Sahay, S., Inam, A., Inam,A., \& Iqbal, S. (2015). Modulation in growth, photosynthesis and yield attributes of black mustard (B. nigra cv. IC247) by interactive effect of wastewater and fly ash under different NPK levels. Cogent Food \& $A g-$ 
riculture. 1:1087632. doi.org/10.1080/23311932 .2015 .1087632

Sinskaia, E.N. (1928). The oleiferous plants and root crops of the family Cruciferae. Bulletin of Applied Botany, Genetics and Plant Breeding. 19:1-648.

Sweeney, A.E., Renner, A.K., Laboski, C., \& Davis, A. (2008). Effect of fertilizer nitrogen on weed emergence and growth. Weed Science. 56:714721. doi.org/10.1614/WS-07-096.1

Tang, L., Wan, K., Cheng, C., Li, R., Wang, D., Pan, J., Tao, Y., Xie, J., \& Chen, F. (2014). Effect of fertilization patterns on the assemblage of weed communities in an upland winter wheat field. Journal of Plant Ecology. 7(1):39-50. doi: 10.1093 / jpe / rtt018

Thomas, J., Kuruvilla, M.K., \& Hrideek, K.T. (2004). Mustard. In: Peter, K.V. (Ed.), Handbook of herbs and spices, Vol. 2. Woodhead Publishing Limited, Cambridge, UK, pp.196-205.

Webb, N., Nichol, C., Wood, J., \& Potter, E. (2013). User Manual for the SunScan Canopy Analysis System type SS1 Version: 2.0, Delta-T Devices Ltd. Retrieved September 11, 2019 from http:// www.delta-t.co.uk/wp-content/uploads/2016/10/ SS1-SunScan-User-Manual-v2-0.pdf 